\title{
Gut-Based Strategies to Reduce Postprandial Glycaemia in Type 2 Diabetes
}

\author{
Md Kamruzzaman ${ }^{1}$, Michael Horowitz ${ }^{2,3}$, Karen L. Jones ${ }^{2,3}$ and Chinmay S. Marathe ${ }^{2,3 *}$ \\ ${ }^{1}$ Department of Applied Nutrition and Food Technology, Islamic University, Kushtia, Bangladesh, ${ }^{2}$ Adelaide Medical School, \\ University of Adelaide, Adelaide, SA, Australia, ${ }^{3}$ Endocrine and Metabolic Unit, Royal Adelaide Hospital, Adelaide, Australia
}

Postprandial glycemic control is an important target for optimal type 2 diabetes management, but is often difficult to achieve. The gastrointestinal tract plays a major role in modulating postprandial glycaemia in both health and diabetes. The various strategies that have been proposed to modulate gastrointestinal function, particularly by slowing gastric emptying and/or stimulating incretin hormone GLP-1, are summarized in this review.

Keywords: gastric emptying, type 2 diabetes, postprandial glucose (PPG), incretin hormones, GLP-1 receptor agonist

\section{OPEN ACCESS}

Edited by:

Peter Flatt,

Ulster University, United Kingdom

Reviewed by:

Bo Ahrén,

Lund University, Sweden

Erin E. Mulvihill,

University of Ottawa, Canada

${ }^{*}$ Correspondence:

Chinmay S. Marathe

chinmay.marathe@adelaide.edu.au

Specialty section: This article was submitted to

Gut Endocrinology,

a section of the journal

Frontiers in Endocrinology

Received: 31 January 2021 Accepted: 16 March 2021

Published: 09 April 2021

Citation:

Kamruzzaman M, Horowitz M, Jones $K L$ and Marathe CS (2021) Gut-Based Strategies

to Reduce Postprandial

Glycaemia in Type 2 Diabetes.

Front. Endocrinol. 12:661877. doi: 10.3389/fendo.2021.661877

\section{INTRODUCTION}

The importance of glycemic control to the optimal management of diabetes has now been clearly established (1). Glycemic control can be estimated in a number of ways - including random blood glucose, fasting glucose, postprandial glucose, oral glucose tolerance test or OGTT [which incorporates both fasting glucose and the glycemic response to an oral glucose load (usually $75 \mathrm{~g}$ )] and glycated hemoglobin or HbA1c (which reflects overall glycaemia over a period of 8-12 weeks). Traditionally, the OGTT has been regarded as the 'gold standard' test for the diagnosis of diabetes, although $\mathrm{HbAlc}$ is increasingly used. Fasting glucose is used extensively for both diagnosis and monitoring of type 2 diabetes. Postprandial glycaemia, in contrast, has received relatively little attention, despite the recognition of its critical importance to overall glycaemia in type 2 diabetes, and probable relevance as an independent risk factor for macrovascular disease (2). Postprandial hyperglycemia is usually the first defect in glucose intolerance (3). Impaired glucose tolerance, defined as abnormal PPG (between 7.8-11.1 mmol) in the presence of a normal fasting glucose i.e., specifically a postprandial glycemic abnormality, is regarded as a 'pre-diabetic state' predisposing to type 2 diabetes. In type 2 diabetes, PPG makes a substantial contribution to overall glycaemia, as measured by $\mathrm{HbAlc}$, and is the dominant contributor (i.e. $>50 \%$ ) when the latter is $\leq 8.0 \%(4,5)$. The significance of targeting PPG to achieve desirable glycemic goals has been increasingly appreciated in the last two decades. In 2001, the ADA published a consensus statement relating to PPG and subsequently, in 2014, the International Diabetes Federation (IDF) released specific strategies for the management of PPG excursions in type 1 and type 2 diabetes advocating the use of dietary strategies (such as low glycemic index foods) and use of anti-diabetic medications (such as GLP-1 agonists) which target postprandial glycaemia $(2,6)$. Postprandial hyperglycemia is not only associated with microvascular disease, but probably increases the risk of cardiovascular complications. The DECODE study reported that PPG predicted all-cause and cardiovascular mortality better than fasting plasma glucose (FPG) in type 2 diabetes (7). 


\section{GASTROINTESTINAL DETERMINANTS OF POSTPRANDIAL GLYCEMIA}

A number of factors impact postprandial glycemia. While these include pre-prandial glycemia, insulin secretion and sensitivity (hepatic and skeletal) and glucagon secretion this review focuses on gastrointestinal factors, particularly gastric emptying, intestinal carbohydrate absorption, and the incretin hormones gastric inhibitory polypeptide or glucose-dependent insulinotropic polypeptide (GIP) and glucagon-like peptide 1 (GLP-1) (6). The significance of the gastrointestinal tract in modulating postprandial glycemia is dependent on glucose tolerance status. One way of evaluating this contribution is by calculating so-called 'gastrointestinal glucose disposal' GIGD; the amount of intravenously administrated glucose required to 'copy' the glucose excursions after the oral glucose load - If $25 \mathrm{~g}$ intravenous glucose is required to copy a $75 \mathrm{~g}$ oral glucose load, GIGD amounts to $100 \times(75-25) / 75=66 \%(8,9)$. In other words, in this instance, the gastrointestinal tract is able to dispose of $50 \mathrm{~g}$ of glucose. In health, GIGD approximate $66 \%$. However, in type 2 diabetes, GIGD is markedly reduced and may even be zero (10). Recent studies have provided important insights into the relevance of gastric emptying and the incretin hormones to GIGD.

\section{GASTRIC EMPTYING}

Gastric emptying is the physiological process by which nutrients are transferred from the stomach to the duodenum at a tightly regulated rate to optimize their digestion and absorption (11). Gastric emptying is a complex coordinated process, involving the smooth muscle of the stomach, neural networks (Auerbach's and Meissner's plexi), vagal and enteric nervous systems, neurotransmitters such as nitric oxide, immune cells and the gastric 'pacemaker cells' known as the Interstitial cells of Cajal (ICC) (11). Ingested solid food is initially retained in the stomach while it is ground into small fragments, the majority $<1 \mathrm{~mm}$ in size, a process known as trituration. The food particles are then propelled across the pylorus into the duodenum, predominantly in a pulsatile manner. The overall rate of gastric emptying is dependent on both the composition and macronutrient content of a meal (12). Liquids are emptied preferentially when compared with solids. For solid emptying, there is typically an initial lag phase of about $20 \mathrm{~min}$, while liquids empty essentially immediately. After the sloid lag phase gastric emptying of nutrient-containing foods (solid or liquid) typically approximates on overall linear pattern over time, whereas emptying of non-nutrient liquids follow a non-linear, volumedependent, mono-exponential pattern. Accordingly, for nutrients, the volume of food ingested does not have a major impact the rate, as opposed to the duration, of emptying. In health, gastric emptying exhibits a wide inter-individual (about 1-3 kcal/min), but lesser intra-individual, variation (13). Abnormally delayed gastric emptying, or gastroparesis, occurs commonly in diabetes. Cross-sectional studies indicate that 30$50 \%$ patients with longstanding, complicated type 1 or 2 diabetes have gastroparesis. A hallmark of gastroparesis at the cellular level is loss of ICC (14). Conversely, gastric emptying may be accelerated in some people with diabetes, particularly well controlled uncomplicated type 2 diabetes (15) and adolescents with type 1 diabetes (16). Thus, the inter-individual variation in emptying is even wider in diabetes than health. Importantly in a given individual the rate of emptying, whether normal, delayed or more rapid, cannot be predicted based on clinical criteria. Whole upper gastrointestinal symptoms including postprandial fullness, nausea, vomiting, bloating, upper abdominal pain, and early satiety (17) are common in diabetes (18) and patients with gastroparesis often present with upper gastrointestinal symptoms, the relationship between the presence of symptoms and gastroparesis is modest at best.

Gastric emptying is a major determinant of postprandial glycemic excursions in both health and diabetes, accounting for a third of the variance in the initial rise in glucose. The relationship of the rate of gastric emptying to PPG is both time and glucose tolerance status-dependent (19). Accordingly, in health, following an oral glucose load.

The early (30 or $60 \mathrm{~min}$ ) rise in plasma glucose is related directly to the rate of emptying, while the relationship to the 120 min value, which is used diagnostically is inverse, however in individuals with impaired glucose tolerance or type 2 diabetes, the relationship shows a 'right-ward' shift such that a direct relationship is observed even beyond $60 \min (19,20)$.

\section{MEASUREMENT OF GASTRIC EMPTYING}

Scintigraphy is the 'gold standard' technique of measuring gastric emptying and allows the precise measurement of both solid and liquid emptying, potentially simultaneously. The American Neurogastroenterology and Motility Society and the Society of Nuclear Medicine have proposed a test meal which contains the equivalent of two large eggs, two slices of bread and strawberry jam $(30 \mathrm{~g})$ with water $(120 \mathrm{ml})$ and comprises $255 \mathrm{kcal}$ (with a composition of $72 \%$ carbohydrate, $24 \%$ protein, $2 \%$ fat and $2 \%$ fiber). The meal is radiolabeled with $1 \mathrm{mCi} 99 \mathrm{Tc}$ sulfur colloid (21). This meal may be suitable for a Western diet, but its applicability globally is questionable. The limitations of scintigraphy relate to radiation exposure and the requirement for specialized nuclear medicine equipment and trained personnel. The best alternative is a stable isotope breath test which, while a notional rather than precise measurement, correlates reasonably with scintigraphy and is non-invasive technique without radiation exposure. Subjects consume a meal containing a ${ }^{13} \mathrm{C}$ labelled substrate, which is enzymatically converted to ${ }^{13} \mathrm{CO}_{2}$ in the liver and excreted through the lungs. Breath samples are collected for 2-4 hours postprandially. Ultrasound can also be used to measure emptying, but is observer dependent and requires highly trained personnel. One of the most common methods of measuring gastric emptying in clinical trials is using the plasma kinetics of oral paracetamol absorption. While inexpensive and simple, it is an imprecise technique that 
cannot be used to assess gastric emptying of solids and is not recommended (22). Single-photon emission computed tomography (SPECT), magnetic resonance imaging (MRI) and 3D ultrasound are also non-invasive procedures able to provide true 3D images of the effect of meals on gastric volume and gastric accommodation, but remain research techniques.

\section{INCRETIN HORMONES}

It has been known since the 1960's that blood glucose levels are much lower following oral, compared with administration of a similar amount of intravenous glucose (23). This reflects the marked increase in insulin secretion following oral glucose, a phenomenon termed the 'incretin effect' (24). In late 1980s, the factors responsible for the incretin effect, the so-called 'incretin' hormones, glucose-dependent insulinotropic polypeptide (GIP) and glucagon-like peptide-1 (GLP-1) were discovered (25). GIP and GLP-1 are gut-derived peptides secreted from specialized entero-endocrine $\mathrm{K}$ (located predominantly proximally in the small intestine) and L (located predominantly more distally in the intestine) cells, respectively. All macronutrients have the capacity to stimulate incretin hormone secretion although their relative potency differs (fat and protein may be more powerful triggers for incretin release than carbohydrates). While low in the fasted state, plasma GLP-1 and GIP levels rise promptly following a meal (26). Circulating GLP-1 and GIP are rapidly degraded by the ubiquitous enzyme, dipeptidyl peptidase-IV (DPP-IV) and renal clearance, such that their half-lives are only a few minutes (27). The incretins both have glucosedependent insulinotropic properties in health and GIP may be the dominant contributor to the incretin effect in health (28). GLP- 1 also slows gastric emptying substantially (whereas GIP has no effect) and suppresses glucagon, the latter in a glucose dependent manner (while GIP may stimulate it) $(29,30)$. A seminal observation was the recognition that the incretin effect is markedly reduced in type 2 diabetes (31). Incretin hormone secretion is essentially normal but the insulinotropic effect of GIP in type 2 diabetes is attenuated markedly (32). While that of GLP-1 is relatively maintained in type 2 diabetes. Intravenous infusion of GLP-1 in pharmacological concentrations reduces not only fasting, but also normalize postprandial glycemia in type 2 diabetes (33). Slowing of gastric emptying is a major mechanism to account for postprandial glucose lowering by exogenous GLP-1, as postprandial plasma insulin levels are usually reduced, rather than greater (34). These observations stimulated the development and subsequent widespread use of 'GLP-1 based' drugs for use in the management of type 2 diabetes. The latter are of two types: 1) GLP-1 receptor agonists and 2) DPP-IV inhibitors. Exenatide, the first GLP-1 receptor agonist, was approved by the FDA in 2005 and is a synthetic version of exendin-4, a peptide derived from saliva of the lizard, Heloderma suspectum, found to have $~ 50 \%$ similarity with human GLP-1, with resistance to DPP-IV degradation and relatively slow systemic clearance (35). Since then, a number of GLP-1 receptor agonists have been developed. These are currently administered subcutaneously once or twice a day (e.g., lixisenatide, liraglutide and exenatide BID) or once a week (e.g. exenatide QW, dulaglutide and semaglutide) (19, 35, 36). An oral formation of semaglutide has recently been developed $(37,38)$. Specific inhibitors of the DPP-IV enzyme prolong the availability of endogenous GLP-1 (and GIP) and are administered orally. A number of compounds in this class are available (e.g. sitagliptin, linagliptin, saxagliptin, vildagliptin and alogliptin) (19, 39, 40).

\section{GUT BASED MANAGEMENT OF POSTPRANDIAL GLYCEMIA (PPG)}

Several gut-based interventions/treatment strategies have been proposed to minimize postprandial glycemic excursions. These interventions can be broadly classified as i) dietary/nonpharmacological and ii) pharmacological (Figure 1).

\section{Dietary Approach}

Nutritional/dietary management (Table 1) of postprandial hyperglycemia is an attractive option and underutilized. It may be of particular relevance to individuals with impaired glucose tolerance where pharmacological therapy is not usually mandatory.

\section{i) Nutrient Preload}

A nutrient preload refers to consumption of a small amount of macronutrient at a fixed interval (30-60 min) before a meal to reduce the postprandial glycemic excursion. These nutrients may reduce postprandial glucose by a number of mechanisms including slowing gastric emptying, stimulating the release of incretins, and other gut peptides and reducing subsequent meal intake. Fat and protein have been best characterized as macronutrient preloads. Because of its higher-calorie content, fat is emptied from the stomach and absorbed relatively more slowly $(71,72)$ and GLP-1 and GIP secretion are triggered by a fat preload $(73,74)$. Ingestion of fat as a preload or direct small intestinal administration both slow gastric emptying and stimulate the release of GLP-1, effects mediated by the interaction of lipolytic products with the small intestine, and partly by CCK. The dominant effect of fat is likely to be via slowing of gastric emptying-this is analogous to the use of olive oil or equivalent to slow the absorption of alcohol-containing beverages (75) (Figure 2). Slowing of gastric emptying is not as marked when fat is mixed with other nutrients; due to low density, in the seated position fat may 'layer' on top of other nutrients and exert little impact initially on emptying $(41,73,74)$. In both health and type 2 diabetes $(42,76)$ whey protein, a by-product of milk, has been the best characterized (43). Soy, or whey-based protein preloads may have a greater impact on postprandial glycemia than fat $(42,77)$. When a whey-based protein preload is taken 30 minutes before a large meal, there is a reduction in postprandial glucose of $28-50 \%$ is associated with increased secretion of insulin, GLP-1, and GIP $(43,44,78)$. The effects of protein are hypothesized to be mediated primarily by amino acids (in the case of whey leucine, isoleucine, and valine). Whey protein is digested quickly, compared to other proteins such as casein, and is 


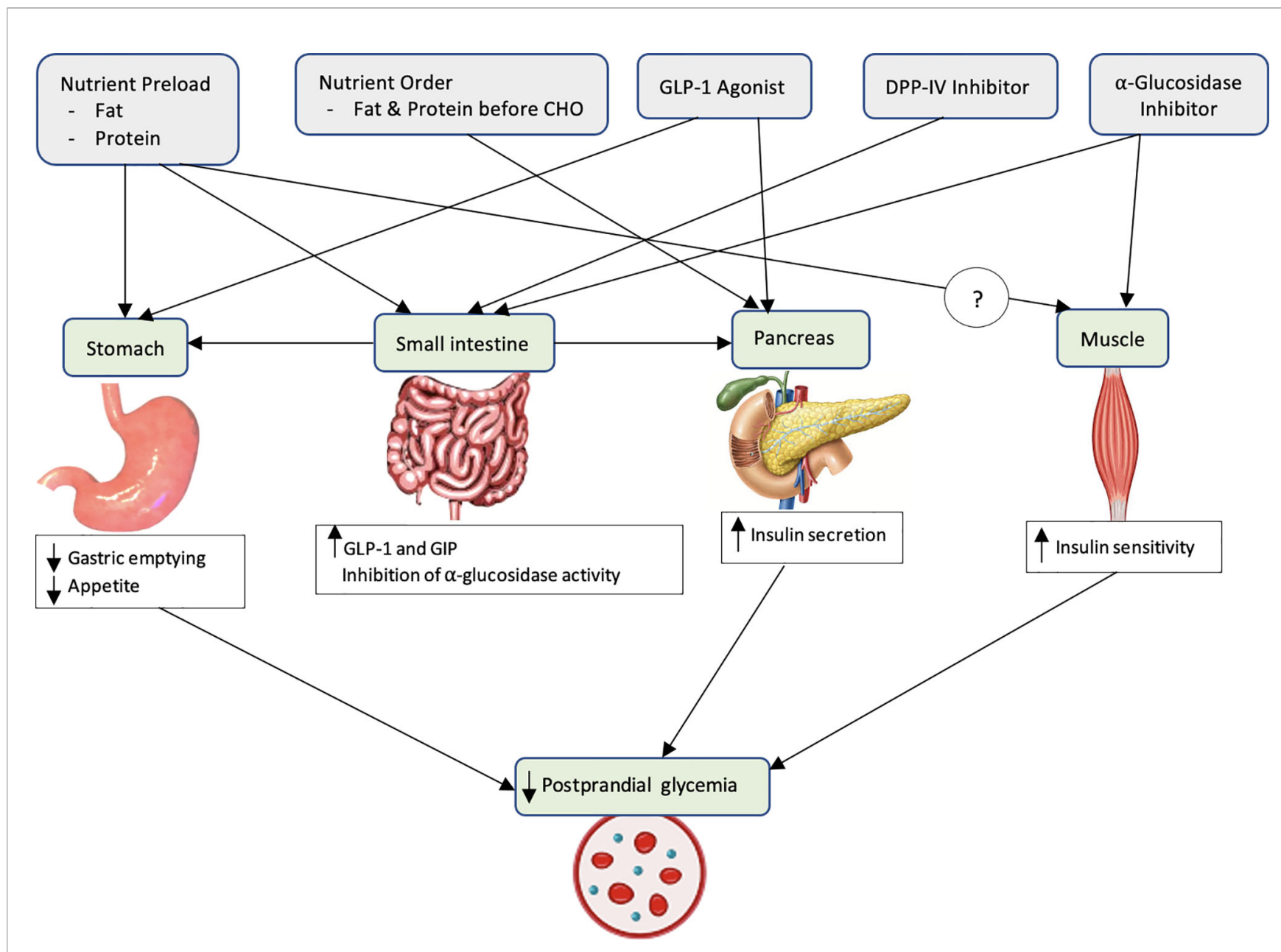

FIGURE 1 | Potential mechanisms of postprandial glucose lowering of various gut-based strategies.

associated with substantial incremental rise in postprandial amino acids which triggers the release of both insulin and glucagon (79).

A potential limitation in the use of protein and fat preloads is that they provide additional energy intake in a group where obesity is very common. On the other hand, the preload has the potential to suppress subsequent energy intake. Consuming oil by itself before a meal, may also be associated with gastrointestinal intolerance, and is unlikely to be culturally acceptable widely. The characteristics of an ideal preload are that it should have the capacity to slow gastric emptying, reduce postprandial glycemia substantially and contain minimal calories. The preload should also be inexpensive, readily available, well tolerated and acceptable by the majority of individuals. The effects of low-calorie preloads have also been evaluated. The artificial sweetener sucralose (with no calories) has no impact on gastric emptying with little, if any, stimulation of GLP-1 [ (46-48). 3-O-methylglucose preload, a nonmetabolized substrate of SGLT1, was reported to slow gastric emptying and stimulate GLP-1 and GIP, to reduce PPG excursions in the first 30 minutes after a meal, when compared with a glucose preload (46). The above studies, relating to the effects of nutrient preloads on postprandial glucose excursions, are limited to acute or short-term interventions, for a maximum period of five weeks. A longer-term intervention study reported a significant lowering of postprandial blood glucose $(\sim 14 \%)$ and HbAlc $(0.3 \%)$, where participants with type 2 diabetes consumed Inzone Preload (consisting only of natural food ingredients including pea-protein, whey protein, egg albumin, $\Omega$ 3/6 fatty acids, whole eggs, apple, rosehip, and sugar beet fiber) (29\% protein) $30 \mathrm{~min}$ before each of three meals daily for 12 weeks (80). Further studies are required.

\section{ii) The Impact of Macronutrient Composition and Sequence on PPG}

Macronutrient composition, sequence and timing of a meal can impact postprandial hyperglycemia by a number of mechanisms, which include slowing of gastric emptying. For example, fat and protein, are both inhibitors of gastric emptying. Accordingly, incorporation of protein and/or fat into a carbohydrate rich meal or changing the proportion of macronutrients has the potential to reduce PPG and thereby, HbA1c. Gannon et al. reported that increasing the ratio of protein and fat, while decreasing ratio of carbohydrate, leads to a $38 \%$ reduction in net mean $24-\mathrm{h}$ integrated glucose area response (including PPG) $(50,81)$. 
TABLE 1 | Dietary approaches to reduce postprandial glycaemia.

\begin{tabular}{|c|c|c|c|}
\hline Strategy & & Mechanism of action & Comments \\
\hline \multirow[t]{5}{*}{ A. Nutrient Preload } & Fat Preload Olive oil (41) & $\begin{array}{l}\text { Delays gastric emptying. } \\
\text { Triggers GLP-1 and GIP }(\sim 15 \mathrm{~min} \\
\text { post intervention) secretion. }\end{array}$ & $\begin{array}{l}\text { Delayed postprandial glucose peak in type } 2 \text { diabetes. } \\
\text { Involves extra energy intake. } \\
\text { May cause gastrointestinal intolerance like nausea and vomiting. } \\
\text { May be culturally unacceptable by individuals. }\end{array}$ \\
\hline & Protein Soy Protein (42) & Delays gastric emptying & Reduced post meal glycaemia by $40-50 \%$ in type 2 diabetes. \\
\hline & Whey Protein (42-45) & $\begin{array}{l}\text { Triggers GLP-1, GIP and insulin } \\
\text { secretion. }\end{array}$ & Less/No extra energy intake. \\
\hline & Artificial Sweetener & No impact on gastric emptying. & Studies performed in healthy individuals. \\
\hline & Sucralose (46-49) & $\begin{array}{l}\text { No impact on postprandial glycaemia, } \\
\text { GLP-1 or GIP secretion. }\end{array}$ & Not tested in type 2 diabetes. \\
\hline \multirow{4}{*}{$\begin{array}{l}\text { B. Altering } \\
\text { Macronutrient } \\
\text { Composition }\end{array}$} & Protein (50-52) & Delays gastric emptying & Reduced postprandial glycaemic excursion by $38-40 \%$. \\
\hline & & Triggers insulin secretion. & Reduced $\mathrm{HbA} 1 \mathrm{c}$ by $0.8-2.2 \%$ in type 2 diabetes. \\
\hline & Fat $(53-56)$ & $\begin{array}{l}\text { Delays gastric emptying. } \\
\text { Increases insulin secretion and } \\
\text { possibly, } \\
\text { insulin sensitivity. }\end{array}$ & $\begin{array}{l}\text { Delayed peak blood glucose in healthy subjects. } \\
\text { Reduced postprandial glucose excursion. } \\
\text { High fat may entail extra energy intake. } \\
\text { May cause gastrointestinal intolerance e.g., nausea and vomiting. }\end{array}$ \\
\hline & Dietary fiber (57-63) & $\begin{array}{l}\text { Delays gastric emptying. } \\
\text { Increases early phase insulin } \\
\text { secretion. } \\
\text { Delays intestinal glucose absorption. }\end{array}$ & $\begin{array}{l}\text { Reduced postprandial glycaemia by } 35-43 \% \text { in healthy subjects } \\
\text { and type } 2 \text { diabetes. } \\
\text { Reduced } \mathrm{HbA} 1 \mathrm{c} \text { level by } \sim 0.5 \% \text {. } \\
\text { Dietary fiber does not involve additional energy intake. }\end{array}$ \\
\hline \multirow{4}{*}{$\begin{array}{l}\text { C. Altering } \\
\text { Sequence of } \\
\text { Macronutrient } \\
\text { Consumption }\end{array}$} & Protein followed by & Delays gastric emptying. & Reduced postprandial glycaemia by $39-50 \%$ in healthy subjects and \\
\hline & Carbohydrates (64-69) & $\begin{array}{l}\text { Increases release GLP-1, GIP, } \\
\text { Cholecystokinin (CCK) and peptide }\end{array}$ & $\begin{array}{l}\text { type } 2 \text { diabetes. Reduced postprandial insulin excursion by } \sim 25 \% \text { in } \\
\text { type } 2 \text { diabetes. }\end{array}$ \\
\hline & & YY. Delays carbohydrate absorption. & Does not involve additional energy intake. \\
\hline & $\begin{array}{l}\text { Protein and Fat } \\
\text { followed by } \\
\text { Carbohydrates } \\
(64,70)\end{array}$ & $\begin{array}{l}\text { Delays gastric emptying rate. } \\
\text { Triggers GLP-1 secretion. }\end{array}$ & $\begin{array}{l}\text { Reduced postprandial glycaemic excursions by } 78 \% \text { and } 60 \% \text { after I } \\
\text { unch and dinner respectively in type } 2 \text { diabetes. Reduced } \mathrm{HbA} 1 \mathrm{C} \text { by } \\
0.3 \% \text { in type } 2 \text { diabetes. }\end{array}$ \\
\hline
\end{tabular}

A Total stomach

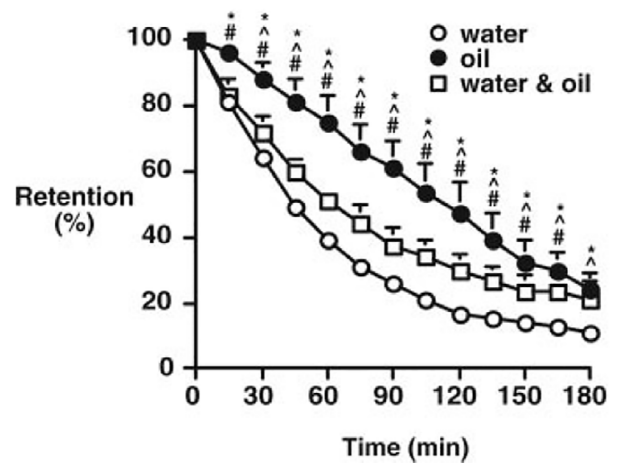

B Blood glucose

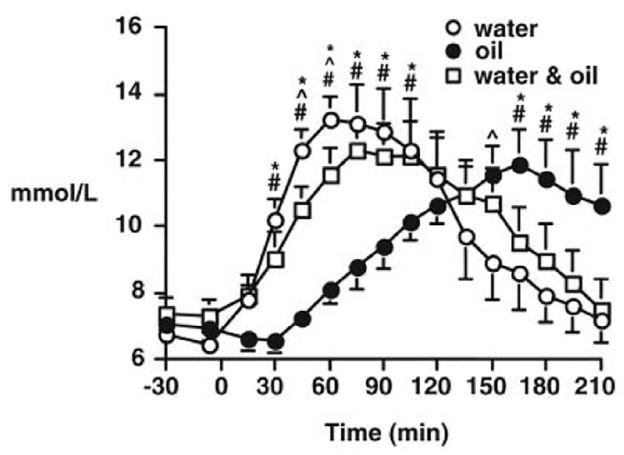

FIGURE 2 | Gastric emptying (A) and blood glucose concentrations (B), after ingestion of a mashed potato meal when either $30 \mathrm{ml}$ olive oil (oil), $30 \mathrm{ml}$ water (water), or $30 \mathrm{ml}$ water with $30 \mathrm{ml}$ olive oil (water and oil) was consumed 30 minutes before the meal by type 2 patients. Data are the mean $\pm \mathrm{SEM}$. ${ }^{*} \mathrm{P}<0.05$, oil vs. water; ${ }^{\#} \mathrm{P}<0.05$, oil vs. water and oil; $\wedge \mathrm{P}<0.05$, water vs. water and oil. [Reprinted with permission from Gentilcore et al. (41)].

Another study conducted by this group demonstrated that an increase in dietary protein from 15 to $30 \%$ is associated with a reduction in PPG of $40 \%$ and HbAlc of $0.8 \%$ in type 2 diabetes (51). The positive impact of protein incorporation is hypothesized to mainly reflect its direct stimulatory effect on insulin secretion and slowing of gastric emptying (82). The addition of fat has been shown to slow gastric emptying and reduce PPG levels (83), but, of necessity, increases the energy load substantially, which has the potential to affect glycemic regulation adversely $(53,84)$. For example, one study, in healthy and obese individuals, reported that an increase in fat intake increase plasma insulin, while reducing insulin sensitivity (54). In another study, in healthy subjects, consumption of high monounsaturated fat was associated with an improvement in insulin sensitivity when compared with a high-saturated-fat diet (53). Nevertheless, the positive effect of monounsaturated fat on insulin sensitivity were inconsistent when the proportion of energy derived from total fat surpassed $38 \%$ of total energy 
$(53,55,85)$. Several studies conducted in healthy and type 2 diabetic individuals have shown that adding low glycemic index carbohydrates to the diet reduces PPG by $\sim 40 \%$ and $\mathrm{HbAlc}$ levels by $\sim 0.5 \%$ (57-60, 86-88), though the impact of a low GI or high-fiber diet is inconclusive (53). Therefore, replacing refined carbohydrates and added sugar with grains, legumes, vegetables, and fruits that are rich in dietary fiber may represent an efficient strategy to reduce PPG.

Another potential approach is to alter the sequence, or order of consumption of macronutrients during a meal. For example, initial ingestion of non-carbohydrate macronutrients and ingestion of carbohydrates last has been reported to be effective in reducing postprandial glucose excursions among individuals with type 2 diabetes and impaired or normal glucose tolerance $(64,89)$. For example, Shukla et al. reported that ingestion of protein and vegetables before carbohydrates leads to a $39 \%$ reduction in postprandial glycemia in individuals with impaired glucose tolerance (64). Likewise, consumption of meat or fish, or vegetables before carbohydrate has been reported to reduce the postprandial glucose peak by almost
$50 \%$, as well as delay it by $30-60 \mathrm{~min}$ and raise the level of GLP-1 and GIP $(65,66)$. However, as well as slowing gastric emptying, Shukla et al. demonstrated that protein and fat initially leads to higher GLP-1 levels and slower carbohydrate absorption, and also suggested that fiber from vegetables may be responsible $(64,67)$. A number of other studies support the beneficial effect of fiber to lower postprandial glycemia $(59,61)$. As compared with the preload, this approach has the indirect advantage of not involving additional energy intake $(70,89)$. Along with a reduction of $\mathrm{PPG}$ excursions, intake of vegetables before carbohydrates may per se also reduce the risk of other metabolic disorders, including cardiovascular disease (90).

\section{Pharmacological Approach GLP-1 Receptor Agonists}

Based on their half-life, GLP-1 receptor agonists (Table 2) can be classified, as either 'short-acting', or 'long-acting'. The 'shortacting' GLP-1 agonists, exenatide BID and lixisenatide, delay gastric emptying profoundly in a dose-dependent manner. The magnitude of the slowing of gastric emptying is also dependent

TABLE 2 | Summary of the pharmacological agents targeting postprandial glycaemia.

\begin{tabular}{|c|c|c|c|c|c|}
\hline Class & Agent Name & $\begin{array}{l}\text { Duration } \\
\text { of action }\end{array}$ & $\begin{array}{c}\text { Mode of } \\
\text { administration }\end{array}$ & Mechanism of action & Comments \\
\hline $\begin{array}{l}\text { Long acting GLP } 1 \text { Agonists } \\
(19,22,91-97)\end{array}$ & $\begin{array}{l}\text { Albiglutide } \\
\text { Dulaglutide } \\
\text { Exenatide XR } \\
\text { Liraglutide } \\
\text { Semaglutide }\end{array}$ & $\begin{array}{l}\text { Half-life } \\
\text { few days }\end{array}$ & $\begin{array}{l}\text { Subcutaneous } \\
\text { injection (Once } \\
\text { daily; once } \\
\text { weekly) }\end{array}$ & $\begin{array}{l}\text { Slows gastric emptying and } \\
\text { increase satiety. } \\
\text { Increases glucose-dependent } \\
\text { insulin secretion. } \\
\text { Reduces glucose-dependent } \\
\text { glucagon secretion. }\end{array}$ & $\begin{array}{l}\text { Less impact on gastric emptying compared to } \\
\text { short-acting GLP-1 Agonists. } \\
\text { More effective in controlling fasting/preprandial } \\
\text { hyperglycaemia. }\end{array}$ \\
\hline $\begin{array}{l}\text { Short acting GLP-1 Agonists } \\
(19,22,91,92,94,95)\end{array}$ & $\begin{array}{l}\text { Exenatide BID } \\
\text { Lixisenatide }\end{array}$ & $\begin{array}{l}\text { Half-life } \\
2.4 \text { to } 8 \\
\text { hours }\end{array}$ & $\begin{array}{l}\text { Subcutaneous } \\
\text { injection (Once } \\
\text { or twice daily) }\end{array}$ & $\begin{array}{l}\text { Delays gastric emptying and } \\
\text { increase satiety. Increases } \\
\text { glucose-dependent insulin } \\
\text { secretion. Reduce glucose- } \\
\text { dependent glucagon secretion. }\end{array}$ & $\begin{array}{l}\text { More effective in slowing gastric emptying and } \\
\text { controlling postprandial hyperglycaemia } \\
\text { compared to long-acting GLP-1 Agonists. } \\
\text { Gastrointestinal intolerance e.g., nausea, } \\
\text { vomiting, diarrhea, may limit uses. }\end{array}$ \\
\hline $\begin{array}{l}\text { GIP receptor Agonists and } \\
\text { Antagonists } \\
(98,99)\end{array}$ & $\begin{array}{l}\text { AC163794 } \\
\left(\text { Pro }^{3}\right) \text { GIP }\end{array}$ & $\begin{array}{l}\text { Long } \\
\text { acting }(>24 \\
\text { hours) }\end{array}$ & $\begin{array}{l}\text { Subcutaneous } \\
\text { injection } \\
\text { (Once daily) }\end{array}$ & Enhances insulin secretion. & $\begin{array}{l}\text { Experiments performed only in mice models } \\
\text { and show significant reduction in overall } \\
\text { hyperglycaemia. } \\
\text { Data evaluating postprandial response not } \\
\text { available. } \\
\text { Human trials are awaited. }\end{array}$ \\
\hline $\begin{array}{l}\text { GIP/GLP-1 receptor Agonists } \\
(22,100-103)\end{array}$ & $\begin{array}{l}\text { Tirzepatide } \\
\text { (LY3298176) }\end{array}$ & $\begin{array}{l}\text { Long } \\
\text { Acting(5 } \\
\text { Days) }\end{array}$ & $\begin{array}{l}\text { Subcutaneous } \\
\text { injection } \\
\text { (Once weekly) }\end{array}$ & $\begin{array}{l}\text { Combined action of both GLP-1 } \\
\text { and GIP as above. }\end{array}$ & $\begin{array}{l}\text { Impressive dose-dependent reduction in } \\
\text { overall glycaemia in type } 2 \text { diabetes. } \\
\text { Data evaluating postprandial response not } \\
\text { available. }\end{array}$ \\
\hline $\begin{array}{l}\text { DPP-4 inhibitors }(19,39,40, \\
94,95,104-106)\end{array}$ & $\begin{array}{l}\text { Alogliptin } \\
\text { Linagliptin } \\
\text { Saxagliptin }\end{array}$ & $\begin{array}{l}\text { Long } \\
\text { acting } \\
\text { (half-life } 3\end{array}$ & $\begin{array}{l}\text { Oral (Once or } \\
\text { twice daily) }\end{array}$ & $\begin{array}{l}\text { Prevent degradation of GLP-1 } \\
\text { and GIP in vivo, prolonging its } \\
\text { action. }\end{array}$ & $\begin{array}{l}\text { Has little or no effect on gastric emptying and } \\
\text { satiety. Modest effect to reduce postprandial } \\
\text { hyperglycaemia. }\end{array}$ \\
\hline
\end{tabular}

Amylin Agonist $(19,95,107-\quad$ Pramlintide 109)

Alpha-glucosidase inhibitors $(95,110-114)$

$\begin{array}{lll}\text { Acarbose } & \text { Short- } & \text { Oral } \\ \text { Miglitol } & \text { acting } & \text { administration } \\ \text { Voglibose } & \text { (half-life } & \text { (Three times } \\ & \sim 2 \text { to } 4 & \text { daily) } \\ & \text { hours) } & \end{array}$

Subcutaneous injection (Three times daily) (half-life 48 min) acting hours)
Delays gastric emptying and increases satiety. Reduces glucagon secretion.

Inhibit maltase-glucoamylase intestinal

( $\alpha$-glucosidase) and pancreatic $\alpha$-amylase which in turns delay gastric emptying, carbohydrate absorption and prompt GLP-1 release.
Modest effect to reduce postprandial hyperglycaemia. Gastrointestinal intolerance e.g., nausea, vomiting. Required to adjust insulin dose to avoid hypoglycemia. Reduce postprandial glucose and $\mathrm{HbA} 1 \mathrm{C}$. Gastrointestinal adverse effects common. 
on the baseline rate of emptying. It is not surprising, therefore, that 'short acting' GLP-1 agonists target postprandial hyperglycemia. It has been conventionally believed that longacting GLP-1 receptor agonists, such as exenatide QW and liraglutide, are much more effective in targeting fasting, rather than postprandial, hyperglycemia and have little, if any, effect on gastric emptying. This concept was supported by the observation that continuous intravenous stimulation of the GLP-1 receptor is associated with tachyphylaxis i.e. lesser slowing of gastric emptying $(91,92,115)$. However, it is now recognized that this concept is incorrect; both exenatide QW (116) and liraglutide (117) have been shown to slow emptying with sustained use, although the magnitude of their effect may be less than that of 'short acting' agonists. Given that modest slowing of emptying may have a major effect on postprandial glucose this is of relevance to their use in the management of type 2 diabetes (116).

Some limitations of the strategy of using GLP-1 agonists for modulating gastric emptying and enhancing incretin secretion should be recognized: i) GLP-1 agonists should probably not be used in patients with existing gastroparesis. In the LEADER study, 'delayed gastric emptying' was reported three times more frequently in the liraglutide than the placebo group (93) ii) Gastrointestinal adverse effects, particularly nausea, vomiting and diarrhea, may limit tolerability. Unfortunately, in the majority of studies these have been assessed by participant self-report which is known to be unreliable (118) iii) the insulinotropic actions of GLP-1-based therapy necessitates adequate endogenous insulin secretory capacity iv) GLP-1 agonists are contraindicated in the rare case of medullary thyroid carcinoma. While recent observational studies and meta-analyses have failed to establish a causal relationship between GLP-1 agonists and acute pancreatitis, this remains potential issue $(94,119)$. A post-hoc analysis of the LEADER trial showed that the GLP-1 receptor agonist, liraglutide, to have an increased risk of gallbladder or biliary tract related events compared with placebo (120). It should be noted, however, that this trial was not specifically designed to assess the risks of gallbladder event rates with liraglutide.

\section{GIP-Based Medications}

There is some renewed interest in GIP-based drugs, especially when co-administered with GLP-1 (GIP/GLP-1 co-agonists) with studies suggesting that both GIP agonism and GIP antagonism may facilitate weight loss in type 2 diabetes. The effects of GIPbased drugs on gastrointestinal motility remain to be studied. However, given that GIP does not impact gastric emptying, it

\section{REFERENCES}

1. Gerich JE. The importance of tight glycemic control. Am J Med (2005) 118:7-11. doi: 10.1016/j.amjmed.2005.07.051

2. I.D.F.G.D. Group. Guideline for management of postmeal glucose in diabetes. Diabetes Res Clin Pract (2014) 103:256-68. doi: 10.1016/j.diabres.2012.08.002

3. Maffettone A, Rinaldi M, Fontanella A. Postprandial hyperglycemia: a new frontier in diabetes management? Ital J Med (2018) 12:108-15. doi: 10.3389/ fgene.2019.00693 appears unlikely that an effect of GIP agonism is unlikely $(22,100)$.

\section{DPP-IV Inhibitors}

DPP-IV inhibitors (e.g. sitagliptin, vildagliptin, saxagliptin, linagliptin, and alogliptin) reduce both pre- and postprandial glucose (95) but have minimal, if any, effect on gastric emptying (104). Postprandial glucose-lowering by DPP-IV inhibitors may, however, be potentiated by a nutrient preload (121) a strategy which warrants additional exploration (105).

\section{Acarbose}

Acarbose, and other alpha-glucosidase inhibitors, such as voglibose, delays the production of monosaccharides from complex carbohydrates by inhibiting the alpha-glucosidase on the brush border membrane of the small intestine (122) to diminish postprandial glucose excursions $(110,122,123)$. However gastrointestinal adverse effects are common (111).

\section{Pramlintide}

The synthetic analog of amylin, which is co-secreted with insulin in the pancreatic beta cells, pramlintide, reduces postprandial glucose in part by delaying gastric emptying. It may also enhance satiety $(107,108,124)$.

\section{CONCLUSIONS}

Modulating gastrointestinal motility (especially slowing gastric emptying) and stimulating the incretin system are major targets for management of postprandial glycemia. A number of strategies, dietary as well as pharmacological, have been introduced. Regarding simple dietary approaches have shown promising results in small studies and larger trials are required to establish efficacy. On the other hand, pharmacological strategies, such as GLP-1 agonists are prescribed widely for type 2 management, but their use is largely empirical. There is a need for studies to evaluate their efficacy under various glycemic conditions and the relationship of the effects of these drugs on glycemic control with those on gastric emptying in an attempt to provide more targeted and personalized management.

\section{AUTHOR CONTRIBUTIONS}

All authors contributed to the article and approved the submitted version.
4. Monnier L, Lapinski H, Colette C. Contributions of fasting and postprandial plasma glucose increments to the overall diurnal hyperglycemia of type 2 diabetic patients: variations with increasing levels of HbA1c. Diabetes Care (2003) 26:881-5. doi: 10.2337/diacare.26.3.881

5. Bonora E, Calcaterra F, Lombardi S, Bonfante N, Formentini G, Bonadonna $\mathrm{RC}$, et al. Plasma glucose levels throughout the day and $\mathrm{HbA}(1 \mathrm{c})$ interrelationships in type 2 diabetes: implications for treatment and monitoring of metabolic control. Diabetes Care (2001) 24:2023-9. doi: $10.2337 /$ diacare.24.12.2023 
6. Association AD. Postprandial blood glucose. Diabetes Care (2001) 24:77578. doi: $10.2337 /$ diacare.24.4.775

7. D.S. Group and E.D.E. Group. Glucose tolerance and cardiovascular mortality: comparison of fasting and 2-hour diagnostic criteria. Arch Internal Med (2001) 161:397. doi: 10.1001/archinte.161.3.397

8. Holst JJ, Knop FK, Vilsbøll T, Krarup T, Madsbad S. Loss of incretin effect is a specific, important, and early characteristic of type 2 diabetes. Diabetes Care (2011) 34(Suppl 2):S251-7. doi: 10.2337/dc11-s227

9. Marathe CS, Rayner CK, Bound M, Checklin H, Standfield S, Wishart J, et al. Small intestinal glucose exposure determines the magnitude of the incretin effect in health and type 2 diabetes. Diabetes (2014) 63:2668-75. doi: $10.2337 / \mathrm{db} 13-1757$

10. Bagger JI, Knop FK, Lund A, Vestergaard H, Holst JJ, Vilsbøll T, et al. Impaired regulation of the incretin effect in patients with type 2 diabetes. J Clin Endocrinol Metab (2011) 96:737-45. doi: 10.1210/jc.2010-2435

11. Goyal RK, Guo Y, Mashimo H. Advances in the physiology of gastric emptying. Neurogastroenterol Motil (2019) 31:e13546. doi: 10.1111/nmo.13546

12. Meyer JH, Elashoff J, Porter-Fink V, Dressman J, Amidon GL. Human postprandial gastric emptying of 1-3-millimeter spheres. Gastroenterology (1988) 94:1315-25. doi: 10.1016/0016-5085(88)90669-5

13. Hunt J, Smith J, Jiang C. Effect of meal volume and energy density on the gastric emptying of carbohydrates. Gastroenterology (1985) 89:1326-30. doi: 10.1016/0016-5085(85)90650-x

14. Grover M, Farrugia G, Lurken MS, Bernard CE, Faussone-Pellegrini MS, Smyrk TC, et al. Cellular changes in diabetic and idiopathic gastroparesis. Gastroenterology (2011) 140:1575-85.e8. doi: 10.1053/j.gastro.2011.01.046

15. Watson LE, Xie C, Wang X, Li Z, Phillips LK, et al. Gastric Emptying in Patients With Well-Controlled Type 2 Diabetes Compared With Young and Older Control Subjects Without Diabetes. J Clin Endocrinol Metab (2019) 104:3311-9. doi: 10.1210/jc.2018-02736

16. Nowak TV, Johnson CP, Kalbfleisch JH, Roza AM, Wood CM, et al. Highly variable gastric emptying in patients with insulin dependent diabetes mellitus. Gut (1995) 37:23-9. doi: 10.1136/gut.37.1.23

17. Enck P, Rathmann W, Spiekermann M, Czerner D, Tschöpe D, et al. Prevalence of gastrointestinal symptoms in diabetic patients and nondiabetic subjects. Z fur Gastroenterologie (1994) 32:637.

18. Ricci J, Siddique R, Stewart W, Sandler R, Sloan S, Farup CE, et al. Upper gastrointestinal symptoms in a US national sample of adults with diabetes. Scandinavian J Gastroenterology (2000) 35:152-9. doi: 10.1080/0036552007 50024317

19. Marathe CS, Rayner CK, Jones KL, Horowitz M. Relationships between gastric emptying, postprandial glycemia, and incretin hormones. Diabetes Care (2013) 36:1396-1405. doi: 10.2337/dc12-1609

20. Marathe CS, Horowitz M, Trahair LG, Wishart JM, Bound M, Lange K, et al. Relationships of early and late glycemic responses with gastric emptying during an oral glucose tolerance test. J Clin Endocrinol Metab (2015) 100:3565-71. doi: 10.1210/JC.2015-2482

21. Abell TL, Camilleri M, Donohoe K, Hasler WL, Lin HC, Maurer AH, et al. Consensus recommendations for gastric emptying scintigraphy: a joint report of the American Neurogastroenterology and Motility Society and the Society of Nuclear Medicine. J Nucl Med Technol (2008) 36:44-54. doi: $10.2967 /$ jnmt.107.048116

22. Horowitz M, Rayner CK, Marathe CS, Wu T, Jones KL. Glucagon-like peptide-1 receptor agonists and the appropriate measurement of gastric emptying. Diabetes Obes Metab (2020) 22:2504-6. doi: 10.1111/dom.14166

23. Rehfeld JF. The origin and understanding of the incretin concept. Front Endocrinol (2018) 9:387. doi: 10.3389/fendo.2018.00387

24. Nauck MA, Meier JJ. The incretin effect in healthy individuals and those with type 2 diabetes: physiology, pathophysiology, and response to therapeutic interventions. Lancet Diabetes Endocrinol (2016) 4:525-36. doi: 10.1016/S2213-8587(15)00482-9

25. Drucker DJ, Habener JF, Holst JJ. Discovery, characterization, and clinical development of the glucagon-like peptides. J Clin Invest (2017) 127:4217-27. doi: 10.1172/JCI97233

26. Pais R, Gribble FM, Reimann F. Stimulation of incretin secreting cells. Ther Adv Endocrinol Metab (2016) 7:24-42. doi: 10.1177/2042018815618177

27. Baggio LL, Drucker DJ. Biology of incretins: GLP-1 and GIP. Gastroenterology (2007) 132:2131-57. doi: 10.1053/j.gastro.2007.03.054
28. Holst JJ. The incretin system in healthy humans: The role of GIP and GLP-1. Metabolism (2019) 96:46-55. doi: 10.1016/j.metabol.2019.04.014

29. Nauck MA, Meier JJ. Incretin hormones: Their role in health and disease. Diabetes Obes Metab (2018) 20(Suppl 1):5-21. doi: 10.1111/dom.13129

30. Marathe CS, Rayner CK, Jones KL, Horowitz M. Effects of GLP-1 and incretin-based therapies on gastrointestinal motor function. Exp Diabetes Res (2011) 2011:279530. doi: 10.1155/2011/279530

31. Nauck M, Stöckmann F, Ebert R, Creutzfeldt W. Reduced incretin effect in type 2 (non-insulin-dependent) diabetes. Diabetologia (1986) 29:46-52. doi: $10.1007 / \mathrm{bf0} 2427280$

32. Knop FK, Vilsbøll T, Højberg PV, Larsen S, Madsbad S, Vølund A, et al. Reduced Incretin Effect in Type 2 Diabetes: Cause or Consequence of the Diabetic State? Diabetes (2007) 56:1951-59. doi: 10.2337/db07-0100

33. Gautier JF, Choukem SP, Girard J. Physiology of incretins (GIP and GLP-1) and abnormalities in type 2 diabetes. Diabetes Metab (2008) 34(Suppl 2): S65-72. doi: 10.1016/s1262-3636(08)73397-4

34. Werner U. Effects of the GLP-1 receptor agonist lixisenatide on postprandial glucose and gastric emptying - preclinical evidence. J Diabetes its Complications (2014) 28:110-4. doi: 10.1016/j.jdiacomp.2013.06.003

35. Hinnen D. Glucagon-like peptide 1 receptor agonists for type 2 diabetes. Diabetes Spectr (2017) 30:202-10. doi: 10.2337/ds16-0026

36. Nauck MA, Meier JJ. Are all GLP-1 agonists equal in the treatment of type 2 diabetes. Eur J Endocrinol (2019) 181:R211-34. doi: 10.1530/EJE-19-0566

37. Drucker DJ. Advances in oral peptide therapeutics. Nat Rev Drug Discovery (2020) 19:277-89. doi: 10.1038/s41573-019-0053-0

38. Pearson S, Kietsiriroje N, Ajjan RA. Oral Semaglutide In The Management Of Type 2 Diabetes: A Report On The Evidence To Date. Diabetes Metab Syndr Obes (2019) 12:2515-29. doi: 10.2147/dmso.S229802

39. Deacon CF. Dipeptidyl peptidase 4 inhibitors in the treatment of type 2 diabetes mellitus. Nat Rev Endocrinol (2020) 16:642-53. doi: 10.1038/s41574-020-0399-8

40. Golightly LK, Drayna CC, McDermott MT. Comparative clinical pharmacokinetics of dipeptidyl peptidase-4 inhibitors. Clin Pharmacokinet (2012) 51:501-14. doi: 10.1007/bf03261927

41. Gentilcore D, Chaikomin R, Jones KL, Russo A, Feinle-Bisset C, Wishart JM, et al. Effects of fat on gastric emptying of and the glycemic, insulin, and incretin responses to a carbohydrate meal in type 2 diabetes. $J$ Clin Endocrinol Metab (2006) 91:2062-7. doi: 10.1210/jc.2005-2644

42. Sun L, Tan KWJ, Han CMS, Leow MK-S, Henry CJ. Impact of preloading either dairy or soy milk on postprandial glycemia, insulinemia and gastric emptying in healthy adults. Eur J Nutr (2017) 56:77-87. doi: 10.1007/s00394-015-1059-y

43. Ma J, Stevens JE, Cukier K, Maddox AF, Wishart JM, Jones KL, et al. Effects of a protein preload on gastric emptying, glycemia, and gut hormones after a carbohydrate meal in diet-controlled type 2 diabetes. Diabetes Care (2009) 32:1600-2. doi: 10.2337/dc09-0723

44. Jakubowicz D, Froy O, Ahrén B, Boaz M, Landau Z, Bar-Dayan Y, et al. Incretin, insulinotropic and glucose-lowering effects of whey protein preload in type 2 diabetes: a randomised clinical trial. Diabetologia (2014) 57:1807-11. doi: 10.1007/s00125-014-3305-x

45. Hall WL, Millward DJ, Long SJ, Morgan LM. Casein and whey exert different effects on plasma amino acid profiles, gastrointestinal hormone secretion and appetite. Br J Nutr (2003) 89:239-48. doi: 10.1079/bjn2002760

46. Wu T, Zhao BR, Bound MJ, Checklin HL, Bellon M, Little TJ, et al. Effects of different sweet preloads on incretin hormone secretion, gastric emptying, and postprandial glycemia in healthy humans. Am J Clin Nutr (2012) 95:7883. doi: 10.3945/ajcn.111.021543

47. Ma J, Chang J, Checklin HL, Young RL, Jones KL, et al. Effect of the artificial sweetener, sucralose, on small intestinal glucose absorption in healthy human subjects. Br J Nutr (2010) 104:803-6. doi: 10.1017/S0007114510001327

48. Ma J, Bellon M, Wishart JM, Young R, Blackshaw LA, et al. Effect of the artificial sweetener, sucralose, on gastric emptying and incretin hormone release in healthy subjects. Am J Physiology-Gastrointestinal Liver Physiol (2009) 296:G735-9. doi: 10.1152/ajpgi.90708.2008

49. Alsunni AA. Effects of Artificial Sweetener Consumption on Glucose Homeostasis and Its Association with Type 2 Diabetes and Obesity. Int $J$ Gen Med (2020) 13:775-85. doi: 10.2147/ijgm.S274760

50. Gannon MC, Nuttall FQ. Effect of a high-protein, low-carbohydrate diet on blood glucose control in people with type 2 diabetes. Diabetes (2004) 53:2375-82. doi: 10.2337/diabetes.53.9.2375 
51. Gannon MC, Nuttall FQ, Saeed A, Jordan K, Hoover H. An increase in dietary protein improves the blood glucose response in persons with type 2 diabetes. Am J Clin Nutr (2003) 78:734-41. doi: 10.1093/ajen/78.4.734

52. Gannon MC, Nuttall FQ. Control of blood glucose in type 2 diabetes without weight loss by modification of diet composition. Nutr Metab (Lond) (2006) 3:16. doi: 10.1186/1743-7075-3-16

53. Riccardi G, Rivellese A. Dietary treatment of the metabolic syndrome-the optimal diet. Br J Nutr (2000) 83:S143-8. doi: 10.1017/s0007114500001082

54. Wuesten O, Balz CH, Bretzel RG, Kloer HU, Hardt PD. Effects of oral fat load on insulin output and glucose tolerance in healthy control subjects and obese patients without diabetes. Diabetes Care (2005) 28:360-5. doi: $10.2337 /$ diacare.28.2.360

55. Vessby B, Uusitupa M, Hermansen K, Riccardi G, Rivellese AA, Tapsell LC, et al. Substituting dietary saturated for monounsaturated fat impairs insulin sensitivity in healthy men and women: The KANWU Study. Diabetologia (2001) 44:312-9. doi: 10.1007/s001250051620

56. Cunningham KM, Read NW. The effect of incorporating fat into different components of a meal on gastric emptying and postprandial blood glucose and insulin responses. Br J Nutr (1989) 61:285-90. doi: 10.1079/ bjn19890116

57. Stenvers DJ, Schouten LJ, Jurgens J, Endert E, Kalsbeek A, Fliers E, et al. Breakfast replacement with a low-glycaemic response liquid formula in patients with type 2 diabetes: a randomised clinical trial. Br J Nutr (2014) 112:504-12. doi: 10.1017/S0007114514001123

58. Thomas D, Elliott EJ. Low glycaemic index, or low glycaemic load, diets for diabetes mellitus. Cochrane Database Syst Rev (2009) 2009:Cd006296. doi: 10.1002/14651858.CD006296.pub2

59. Yuan JY, Smeele RJ, Harington KD, van Loon FM, Wanders AJ, Venn BJ, et al. The effects of functional fiber on postprandial glycemia, energy intake, satiety, palatability and gastrointestinal wellbeing: a randomized crossover trial. Nutr J (2014) 13:76. doi: 10.1186/1475-2891-13-76

60. Post RE, Mainous AG, King 3DE, Simpson KN. Dietary fiber for the treatment of type 2 diabetes mellitus: a meta-analysis. J Am Board Fam Med (2012) 25:16-23. doi: 10.3122/jabfm.2012.01.110148

61. Bhoite R. Effects of a Fiber-Rich Nutritional Supplement on Postprandial Glycemic Response and Lipid Parameters in Overweight Adults with and without Impaired Fasting Glucose in India. J Diabetes Metab (2020) 11:1-7. doi: 10.35248/2155-6156.20.11.841

62. Repin N, Kay BA, Cui SW, Wright AJ, Duncan AM, Douglas Goff H, et al. Investigation of mechanisms involved in postprandial glycemia and insulinemia attenuation with dietary fibre consumption. Food Funct (2017) 8:2142-54. doi: 10.1039/c7fo00331e

63. Yu K, Ke MY, Li WH, Zhang SQ, Fang XC. The impact of soluble dietary fibre on gastric emptying, postprandial blood glucose and insulin in patients with type 2 diabetes. Asia Pac J Clin Nutr (2014) 23:210-8. doi: 10.6133/ apjcn.2014.23.2.01

64. Shukla AP, Dickison M, Coughlin N, Karan A, Mauer E, Truong W, et al. The impact of food order on postprandial glycaemic excursions in prediabetes. Diabetes Obes Metab (2019) 21:377-81. doi: 10.1111/dom.13503

65. Kuwata H, Iwasaki M, Shimizu S, Minami K, Maeda H, Seino S, et al. Meal sequence and glucose excursion, gastric emptying and incretin secretion in type 2 diabetes: a randomised, controlled crossover, exploratory trial. Diabetologia (2016) 59:453-61. doi: 10.1007/s00125-015-3841-z

66. Nishino K, Sakurai M, Takeshita Y, Takamura T. Consuming carbohydrates after meat or vegetables lowers postprandial excursions of glucose and insulin in nondiabetic subjects. J Nutr Sci Vitaminol (2018) 64:316-20. doi: $10.3177 /$ jnsv. 64.316

67. Shukla AP, Andono J, Touhamy SH, Casper A, Iliescu RG, Mauer E, et al. Carbohydrate-last meal pattern lowers postprandial glucose and insulin excursions in type 2 diabetes. BMJ Open Diabetes Res Care (2017) 5:e000440. doi: 10.1136/bmjdrc-2017-000440

68. Sun L, Goh HJ, Govindharajulu P, Leow MK, Henry CJ. Postprandial glucose, insulin and incretin responses differ by test meal macronutrient ingestion sequence (PATTERN study). Clin Nutr (2020) 39:950-7. doi: 10.1016/j.clnu.2019.04.001

69. Bae JH, Cho YM. Effect of Nutrient Preload and Food Order on Glucose, Insulin, and Gut Hormones. J Korean Diabetes (2018) 19:193-9. doi: $10.4093 / \mathrm{jkd} .2018 .19 .4 .193$
70. Tricò D, Filice E, Trifirò S, Natali A. Manipulating the sequence of food ingestion improves glycemic control in type 2 diabetic patients under free-living conditions. Nutr Diabetes (2016) 6:e226. doi: 10.1038/nutd.2016.33

71. Lin HC, Zhao X-T, Wang L. Fat absorption is not complete by midgut but is dependent on load of fat. Am J Physiology-Gastrointestinal Liver Physiol (1996) 271:G62-7. doi: 10.1152/ajpgi.1996.271.1.G62

72. Luscombe-Marsh ND, Seimon RV, Bollmeyer E, Wishart JM, Wittert GA, Horowitz M, et al. Acute effects of oral preloads with increasing energy density on gastric emptying, gut hormone release, thermogenesis and energy intake, in overweight and obese men. Asia Pac J Clin Nutr (2013) 22:380-90. doi: 10.6133/apjen.2013.22.3.11

73. Feinle C, O'Donovan D, Doran S, Andrews JM, Wishart J, et al. Effects of fat digestion on appetite, APD motility, and gut hormones in response to duodenal fat infusion in humans. Am J Physiology-Gastrointestinal Liver Physiol (2003) 284:G798-807. doi: 10.1152/ajpgi.00512.2002

74. Herrmann C, Göke R, Richter G, Fehmann H-C, Arnold R, Göke B, et al. Glucagon-like peptide- 1 and glucose-dependent insulin-releasing polypeptide plasma levels in response to nutrients. Digestion (1995) 56:117-26. doi: 10.1159/000201231

75. Cederbaum AI. Alcohol metabolism. Clin Liver Dis (2012) 16:667-85. doi: 10.1016/j.cld.2012.08.002

76. Tricò D, Frascerra S, Baldi S, Mengozzi A, Nesti L, et al. The insulinotropic effect of a high-protein nutrient preload is mediated by the increase of plasma amino acids in type 2 diabetes. Eur J Nutr (2019) 58:2253-61. doi: 10.1007/s00394-018-1778-y

77. Stevenson EJ, Allerton DM. The role of whey protein in postprandial glycaemic control. Proc Nutr Soc (2018) 77:42-51. doi: 10.1017/S0029665117002002

78. Giezenaar C, Trahair LG, Luscombe-Marsh ND, Hausken T, Standfield S, Jones $\mathrm{KL}$, et al. Effects of randomized whey-protein loads on energy intake, appetite, gastric emptying, and plasma gut-hormone concentrations in older men and women. Am J Clin Nutr (2017) 106:865-77. doi: 10.3945/ajcn.117.154377

79. Nilsson M, Stenberg M, Frid AH, Holst JJ, Björck IM. Glycemia and insulinemia in healthy subjects after lactose-equivalent meals of milk and other food proteins: the role of plasma amino acids and incretins. Am J Clin Nutr (2004) 80:1246-53. doi: 10.1093/ajcn/80.5.1246

80. Li CJ, Norstedt G, Hu ZG, Yu P, Li DQ, Li J, et al. Effects of a Macro-Nutrient Preload on Type 2 Diabetic Patients. Front Endocrinol (Lausanne) (2015) 6:139. doi: 10.3389/fendo.2015.00139

81. Gannon MC, Nuttall FQ. Control of blood glucose in type 2 diabetes without weight loss by modification of diet composition. Nutr Metab (2006) 3:1-8. doi: 10.1186/1743-7075-3-16

82. Tay J, Thompson CH, Brinkworth GD. Glycemic variability: assessing glycemia differently and the implications for dietary management of diabetes. Annu Rev Nutr 35 (2015) 35:389-424. doi: 10.1146/annurevnutr-121214-104422

83. Mahan LK, Raymond JL. Krause's Food \& the Nutrition Care Process. In: E-Book, Mea Edition. Amsterdam, Netherlands: Elsevier (2016).

84. Homko C, Duffy F, Friedenberg F, Boden G, Parkman H. Effect of dietary fat and food consistency on gastroparesis symptoms in patients with gastroparesis. Neurogastroenterol Motil (2015) 27:501-8. doi: 10.1111/ nmo. 12519

85. Gulseth HL, Gjelstad IM, Tiereny AC, McCarthy D, Lovegrove JA, et al. Effects of dietary fat on insulin secretion in subjects with the metabolic syndrome. Eur J Endocrinol (2019) 180:321-8. doi: 10.1530/EJE-19-0022

86. Evert AB, Boucher JL, Cypress M, Dunbar SA, Franz MJ, et al. Nutrition therapy recommendations for the management of adults with diabetes. Diabetes Care (2014) 37:S120-43. doi: 10.2337/dc14-S120

87. Akhtar S, Layla A, Sestili P, Ismail T, Afzal K, Rizvanov AA, et al. Glycemic and Insulinemic Responses of Vegetables and Beans Powders Supplemented Chapattis in Healthy Humans: A Randomized, Crossover Trial. Bio Med Res Int (2019) 2019:7425367. doi: 10.1155/2019/7425367

88. Ojo O, Ojo OO, Adebowale F, Wang XH. The Effect of Dietary Glycaemic Index on Glycaemia in Patients with Type 2 Diabetes: A Systematic Review and Meta-Analysis of Randomized Controlled Trials. Nutrients (2018) 10 (3):373. doi: 10.3390/nu10030373

89. Nesti L, Mengozzi A, Tricò D. Impact of nutrient type and sequence on glucose tolerance: physiological insights and therapeutic implications. Front Endocrinol (2019) 10:144. doi: 10.3389/fendo.2019.00144 
90. Imai S, Fukui M, Ozasa N, Ozeki T, Kurokawa M, Komatsu T, et al. Eating vegetables before carbohydrates improves postprandial glucose excursions. Diabetic Med (2013) 30:370. doi: 10.1111/dme.12073

91. Madsbad S, Holst JJ. Treatment with GLP-1 Receptor Agonists. In: E Bonora, R DeFronzo, editors. Diabetes Epidemiology, Genetics, Pathogenesis, Diagnosis, Prevention, and Treatment. Endocrinology. Cham: Springer (2018). doi: 10.1007/978-3-319-45015-5_20

92. Umapathysivam MM, Lee MY, Jones KL, Annink CE, Cousins CE, Trahair LG, et al. Comparative effects of prolonged and intermittent stimulation of the glucagon-like peptide 1 receptor on gastric emptying and glycemia. Diabetes (2014) 63:785-90. doi: 10.2337/db13-0893

93. Jelsing J, Vrang N, Hansen G, Raun K, Tang-Christensen M. Liraglutide: shortlived effect on gastric emptying - long lasting effects on body weight. Diabetes Obes Metab (2012) 14:531-8. doi: 10.1111/j.1463-1326.2012.01557.x

94. Abd El Aziz M, Cahyadi O, Meier JJ, Schmidt WE, Nauck MA. Incretinbased glucose-lowering medications and the risk of acute pancreatitis and malignancies: a meta-analysis based on cardiovascular outcomes trials. Diabetes Obes Metab (2020) 22:699-704. doi: 10.1111/dom.13924

95. Phillips LK, Deane AM, Jones KL, Rayner CK, Horowitz M. Gastric emptying and glycaemia in health and diabetes mellitus. Nat Rev Endocrinol (2015) 11:112. doi: 10.1038/nrendo.2014.202

96. Kim D, MacConell L, Zhuang D, Kothare PA, Trautmann M, Fineman M, et al. Effects of once-weekly dosing of a long-acting release formulation of exenatide on glucose control and body weight in subjects with type 2 diabetes. Diabetes Care (2007) 30:1487-93. doi: 10.2337/dc06-2375

97. Garber AJ. Long-acting glucagon-like peptide 1 receptor agonists: a review of their efficacy and tolerability. Diabetes Care (2011) 34:S279-84. doi: 10.2337/ dc11-s231

98. Irwin N, Flatt PR. Therapeutic potential for GIP receptor agonists and antagonists. Best Pract Res Clin Endocrinol Metab (2009) 23:499-512. doi: 10.1016/j.beem.2009.03.001

99. Gault VA, Irwin N, Green BD, McCluskey JT, Greer B, Bailey CJ, et al. Chemical ablation of gastric inhibitory polypeptide receptor action by daily (Pro3)GIP administration improves glucose tolerance and ameliorates insulin resistance and abnormalities of islet structure in obesity-related diabetes. Diabetes (2005) 54:2436-46. doi: 10.2337/diabetes.54.8.2436

100. Urva S, Coskun T, Loghin C, Cui X, Beebe E, O'Farrell L, et al. The novel dual glucose-dependent insulinotropic polypeptide and glucagon-like peptide-1 (GLP-1) receptor agonist tirzepatide transiently delays gastric emptying similarly to selective long-acting GLP-1 receptor agonists. Diabetes Obes Metab (2020) 22:1886-91. doi: 10.1111/dom.14110

101. Willard FS, Douros JD, Gabe MB, Showalter AD, Wainscott DB, Suter TM, et al. Tirzepatide is an imbalanced and biased dual GIP and GLP-1 receptor agonist. JCI Insight (2020) 5. doi: 10.1172/jci.insight.140532

102. Holst JJ, Rosenkilde MM. Recent advances of GIP and future horizons. Peptides (2020) 125:170230. doi: 10.1016/j.peptides.2019.170230

103. Min T, Bain SC. The Role of Tirzepatide, Dual GIP and GLP-1 Receptor Agonist, in the Management of Type 2 Diabetes: The SURPASS Clinical Trials. Diabetes Ther (2021) 12:143-57. doi: 10.1007/s13300-020-00981-0

104. Stevens JE, Buttfield M, Wu T, Hatzinikolas S, Pham H, Lange K, et al. Effects of sitagliptin on gastric emptying of, and the glycaemic and blood pressure responses to, a carbohydrate meal in type 2 diabetes. Diabetes Obes Metab (2020) 22:51-8. doi: 10.1111/dom.13864

105. Ahrén B, Landin-Olsson M, Jansson P-A, Svensson M, Holmes D, Schweizer A, et al. Inhibition of dipeptidyl peptidase- 4 reduces glycemia, sustains insulin levels, and reduces glucagon levels in type 2 diabetes. J Clin Endocrinol Metab (2004) 89:2078-84. doi: 10.1210/jc.2003-031907

106. Capuano A, Sportiello L, Maiorino MI, Rossi F, Giugliano D, Esposito K, et al. Dipeptidyl peptidase-4 inhibitors in type 2 diabetes therapy-focus on alogliptin. Drug design Dev Ther (2013) 7:989-1001. doi: 10.2147/ dddt.S37647

107. Schmitz O, Brock B, Rungby J. Amylin agonists: a novel approach in the treatment of diabetes. Diabetes (2004) 53:S233-8. doi: 10.2337/ diabetes.53.suppl_3.s233

108. Maggs DG, Fineman M, Kornstein J, Burrell T, Schwartz S, Wang Y, et al. Pramlintide reduces postprandial glucose excursions when added to insulin lispro in subjects with type 2 diabetes: a dose-timing study. Diabetes/ Metabolism Res Rev (2004) 20:55-60. doi: 10.1002/dmrr.419
109. Leahy JL, Aleppo G, Fonseca VA, Garg SK, Hirsch IB, et al. Optimizing Postprandial Glucose Management in Adults With Insulin-Requiring Diabetes: Report and Recommendations. J Endocrine Soc (2019) 3:194257. doi: 10.1210/js.2019-00222

110. Chiasson J-L, Josse RG, Gomis R, Hanefeld M, Karasik A, Laakso M, et al. Acarbose for prevention of type 2 diabetes mellitus: the STOP-NIDDM randomised trial. Lancet (2002) 359(9323):2072. doi: 10.1016/S0140-6736 (02)08905-5

111. Hanefeld M. Cardiovascular benefits and safety profile of acarbose therapy in prediabetes and established type 2 diabetes. Cardiovasc Diabetol (2007) 6:110. doi: $10.1186 / 1475-2840-6-20$

112. Segal P, Feig PU, Schernthaner G, Ratzmann KP, Rybka J, et al. The efficacy and safety of miglitol therapy compared with glibenclamide in patients with NIDDM inadequately controlled by diet alone. Diabetes Care (1997) 20:68791. doi: $10.2337 /$ diacare.20.5.687

113. Ihana N, Tsujimoto T, Yamamoto-Honda R, Kishimoto M, Kajio H, Noto H, et al. Improvement of both fasting and postprandial glycemic control by the two-step addition of miglitol and mitiglinide to basal insulin therapy: a pilot study. Diabetol Metab Syndr (2014) 6:48. doi: 10.1186/1758-5996-6-48

114. DiNicolantonio JJ, Bhutani J, O'Keefe JH. Acarbose: safe and effective for lowering postprandial hyperglycaemia and improving cardiovascular outcomes. Open Heart (2015) 2:e000327. doi: 10.1136/openhrt-2015-000327

115. Nauck MA, Kemmeries G, Holst JJ, Meier JJ. Rapid tachyphylaxis of the glucagon-like peptide 1-induced deceleration of gastric emptying in humans. Diabetes (2011) 60:1561-5. doi: 10.2337/db10-0474

116. Jones KL, Huynh LQ, Hatzinikolas S, Rigda RS, Phillips LK, et al. Exenatide once weekly slows gastric emptying of solids and liquids in healthy, overweight people at steady-state concentrations. Diabetes Obes Metab (2020) 22:788-97. doi: 10.1111/dom.13956

117. Halawi H, Khemani D, Eckert D, O'Neill J, Kadouh H, et al. Effects of liraglutide on weight, satiation, and gastric functions in obesity: a randomised, placebo-controlled pilot trial. Lancet Gastroenterology Hepatology (2017) 2:890-9. doi: 10.1016/S2468-1253(17)30285-6

118. Du YT, Rayner CK, Jones KL, Talley NJ, Horowitz M. Gastrointestinal Symptoms in Diabetes: Prevalence, Assessment, Pathogenesis, and Management. Diabetes Care (2018) 41:627-37. doi: 10.2337/dc17-1536

119. Meier JJ, Nauck MA. Risk of pancreatitis in patients treated with incretin-based therapies. Diabetologia (2014) 57:1320-4. doi: 10.1007/s00125-014-3231-y

120. Nauck MA, Muus Ghorbani ML, Kreiner E, Saevereid HA, Buse JB. Effects of Liraglutide Compared With Placebo on Events of Acute Gallbladder or Biliary Disease in Patients With Type 2 Diabetes at High Risk for Cardiovascular Events in the LEADER Randomized Trial. Diabetes Care (2019) 42:1912-20. doi: 10.2337/dc19-0415

121. Wu T, Little TJ, Bound MJ, Borg M, Zhang X, et al. A protein preload enhances the glucose-lowering efficacy of vildagliptin in type 2 diabetes. Diabetes Care (2016) 39:511-7. doi: 10.2337/dc15-2298

122. Laube H. Acarbose. Clin Drug Invest (2002) 22:141-56. doi: 10.2165/ 00044011-200222030-00001

123. Nair NS, Brennan IM, Little TJ, Gentilcore D, Hausken T, Jones KL, et al. Reproducibility of energy intake, gastric emptying, blood glucose, plasma insulin and cholecystokinin responses in healthy young males. $\mathrm{Br} \mathrm{J} \mathrm{Nutr}$ (2008) 101:1094-102. doi: 10.1017/S0007114508042372

124. Weyer C, Gottlieb A, Kim DD, Lutz K, Schwartz S, Gutierrez M, et al. Pramlintide reduces postprandial glucose excursions when added to regular insulin or insulin lispro in subjects with type 1 diabetes: a dose-timing study. Diabetes Care (2003) 26:3074-9. doi: 10.1002/dmrr.419

Conflict of Interest: The authors declare that the research was conducted in the absence of any commercial or financial relationships that could be construed as a potential conflict of interest.

Copyright $\odot 2021$ Kamruzzaman, Horowitz, Jones and Marathe. This is an openaccess article distributed under the terms of the Creative Commons Attribution License (CC BY). The use, distribution or reproduction in other forums is permitted, provided the original author(s) and the copyright owner(s) are credited and that the original publication in this journal is cited, in accordance with accepted academic practice. No use, distribution or reproduction is permitted which does not comply with these terms. 